NOTE

\title{
Enzymatic activities of epiphytic and benthic thraustochytrids involved in organic matter degradation
}

\author{
Lucia Bongiorni*, Antonio Pusceddu, Roberto Danovaro \\ Department of Marine Science, Polytechnic University of Marche, Via Brecce Bianche, 60131 Ancona, Italy
}

\begin{abstract}
Thraustochytrids are marine osmo-heterotrophic protists which have been isolated from different habitats and substrates. These organisms are typically encountered in association with refractory substrates, but the extent of their role in organic matter decomposition is still unknown. We isolated 11 thraustochytrid strains from different substrates and tested all species for their potential constitutive ecto- (cell-surface associated) and exo- (free released) enzymatic activities. Our results indicate that the investigated strains exhibited a wide spectrum of enzymes involved in the hydrolysis of all classes of organic compounds, suggesting that thraustochytrids are capable of degrading a large variety of substrates. The enzymatic pools were similar among all strains, and exhibited a good production of lipase, a selection of protease and a poor pool of carbohydrate degradation enzymes. However, different isolates displayed different spectra and intensities of enzymatic activities. The comparison of enzymatic activities of 2 thraustochytrid strains and the total enzymatic activities measured in their natural substrates suggested that thraustochytrids, although representing a minor fraction of the total benthic microbial biomass, are contributors to the degradation of highly refractory organic compounds.
\end{abstract}

KEY WORDS: Thraustochytrids · Enzymatic activities · Organic matter degradation · Marine sediments Resale or republication not permitted without written consent of the publisher

\section{INTRODUCTION}

The role of fungi and osmo-heterotrophic protists in benthic detrital food webs has received little attention to date (Benner et al. 1984, Wong et al. 1998, Raghukumar 2002). Thraustochytrids are osmo-heterotrophic protists, which are widely distributed in most marine habitats (from coastal to deep seas), reaching high densities in substrates characterised by a highly refractory composition (Raghukumar 2002). Thraustochytrids are particularly abundant in marine sediments typically characterised by the accumulation of large amounts of organic matter recalcitrant to enzymatic decomposition (Santangelo et al. 2000, Bongiorni \& Dini 2002) and have also been observed to grow opportunistically in sediments characterised by fish-farm biodeposition (Bongiorni et al. 2005).
Thraustochytrids generally represent a negligible fraction of microbial abundance and a minor fraction of the total benthic microbial biomass (Bongiorni \& Dini 2002, Bongiorni et al. 2005). However, their role in the degradation of different substrates and mineralisation of organic matter has been hypothesised as significant, with regard to their ability to pervade various solid substrates (Raghukumar 2002). At present, the only available information on their enzymatic activities deals with a few species isolated from the water column, mangrove leaves, brown algae and faecal pellets for a limited number of enzymes (Bahnweg 1979a,b, Raghukumar et al. 1994, Sharma et al. 1994, Bremer \& Talbot 1995, Raghukumar \& Raghukumar 1999).

In the present study, the enzymatic profiles of 11 strains isolated from different marine substrates were investigated under fixed culture conditions. We then 
measured the exo- (free released) and ecto- (cellsurface associated) enzymatic activities of a subset of enzymes produced by all strains, to quantify the potential capability of thraustochytrids in degrading attached and free substrates. Additional measurements of total enzymatic activities in origin sediments of 2 of the 11 cultured strains were also carried out in order to provide a first estimate of the potential thraustochytrid contribution to organic matter degradation in marine sediments.

\section{MATERIALS AND METHODS}

Strain isolation and culture. Thraustochytrids were isolated from a variety of substrates (see Table 1 for details). After accurate washing with sterile artificial seawater, aliquots of the substrate and/or sediments were plated on Modified Vishniac's Medium $(0.1 \%$ glucose, $0.01 \%$ yeast extract, $0.01 \%$ peptone, $0.1 \%$ gelatine hydrolysate, $1.2 \%$ agar in seawater, pH 7.0) or baited with sterile pine pollen (Raghukumar 2002). Strains were incubated at $20 \pm 1{ }^{\circ} \mathrm{C}$ until the appearance of colonies (within 3 to $7 \mathrm{~d}$ ). Cells were then transferred to fresh agar plates or pine pollen suspensions, and supplemented with antibiotics $\left(1 \mathrm{mg} \mathrm{m}^{-1}\right.$ of penicillin $\mathrm{G}$ and streptomycin sulphate) to suppress bacterial growth.

Enzymatic profiles. We grew 11 axenic strains in the liquid medium (see 'Strain isolation and culture' above for description) under continuous gentle shaking (150 rpm), till the late exponential growth phase was reached (ca. $96 \mathrm{~h}$ ). Bacterial contamination was checked by epifluorescence microscopy after DAPI staining (Porter \& Feig 1980). Cells were harvested by centrifugation $(1000 \times g)$, washed with sterile artificial seawater and then resuspended to be tested for enzymatic activities. First, all strains were tested for the presence/absence of 19 different enzymes using the semi-quantitative API-ZYM system (Biomérieux; Tiquia 2002). Small sub-aliquots $(65 \mu \mathrm{l})$, corresponding to a cell density varying between 2.0 and $4.0 \times 10^{5}$ cells $\mathrm{ml}^{-1}$, were inoculated in the API-ZYM strip wells. Wells were checked under a stereomicroscope to ensure the presence of cells and then incubated overnight at $20 \pm 1^{\circ} \mathrm{C}$. Presence/absence of the different enzymes and intensity of each reaction were detected according to a colorimetric scale (Tiquia 2002).

Enzymatic activities. Ecto- and exo-enzymatic activities of isolated strains were quantified fluorometrically by the cleavage of fluorogenic substrates for L-aminopeptidase, $\beta$-D-glucosidase, $\beta$-D-galactosidase, alkaline-phosphatase, and lipase (Hoppe 1993). Saturating substrate concentrations were determined using increasing concentrations of L-leucine-4-methylcoumarinyl-7-amide, 4-methylumbelliferone $\beta$-D-glucopyranoside, 4 -methylumbelliferone $\beta$-D-galactoside, 4-methylumbelliferone phosphate $(20,50,100,200$ and $400 \mu \mathrm{M})$ and 4 -methylumbelliferone stearate $(8,20,40$,

Table 1. Environments and substrates from which thraustochytrids were isolated

\begin{tabular}{|c|c|c|c|c|}
\hline Strain & Habitat & Date & Location & Forms on pollen \\
\hline MAN2 & $\begin{array}{l}\text { Senescent mangrove leaves } \\
\text { (Bruguiera sp.) }\end{array}$ & Apr 2004 & $\begin{array}{l}\text { Bunaken, north Sulawesi } \\
\text { (Indonesia) }\end{array}$ & Clustered cells \\
\hline MAN6B & $\begin{array}{l}\text { Senescent mangrove leaves } \\
\text { (Bruguiera sp.) }\end{array}$ & Apr 2004 & $\begin{array}{l}\text { Bunaken, north Sulawesi } \\
\text { (Indonesia) }\end{array}$ & Clustered cells \\
\hline FAN5 & $\begin{array}{l}\text { Senescent seagrass leaves } \\
\text { (Enhalus acoroides) }\end{array}$ & Apr 2004 & $\begin{array}{l}\text { Bunaken, north Sulawesi } \\
\text { (Indonesia) }\end{array}$ & Clustered cells \\
\hline ULV B & Green algae Ulva rigida & May 2004 & $\begin{array}{l}\text { Palombina Beach, Ancona } \\
\text { (Italy) }\end{array}$ & Single round cells \\
\hline ULV R & Green algae Ulva rigida & May 2004 & $\begin{array}{l}\text { Palombina Beach, Ancona } \\
\text { (Italy) }\end{array}$ & Single round cells, pink pigmentation \\
\hline CR2 & Dead crab exoskeleton & May 2004 & $\begin{array}{l}\text { Palombina Beach, Ancona } \\
\text { (Italy) }\end{array}$ & Single round cells \\
\hline GR2-1 & Dead crab exoskeleton & May 2004 & $\begin{array}{l}\text { Palombina Beach, Ancona } \\
\text { (Italy) }\end{array}$ & Single round cells \\
\hline Sar3 & Sand & Jan 2003 & $\begin{array}{l}\text { Poetto Beach, Sardinia } \\
\text { (Italy) }\end{array}$ & Clustered cells \\
\hline GORO2 & Mud & May 2004 & $\begin{array}{l}\text { Goro Lagoon, mussel farm } \\
\text { (Italy) }\end{array}$ & Single round cells \\
\hline PAL & Sand & Feb 2004 & $\begin{array}{l}\text { Palombina Beach, Ancona } \\
\text { (Italy) }\end{array}$ & Single round cells \\
\hline POR & Sand-mud & Feb 2004 & Ancona Port (Italy) & Single round cells \\
\hline
\end{tabular}


80 and $160 \mu \mathrm{M})$, respectively. Among tested thraustochytrid strains, saturating concentrations varied between 200 and $400 \mu \mathrm{M}$ for L-aminopeptidase, $\beta$-Dglucosidase, $\beta$-D-galactosidase, and alkaline-phosphatase activities, and between 80 and $160 \mu \mathrm{M}$ for lipase activity. All analyses were carried out in triplicate. Ecto-enzymatic activities (i.e. activities associated with the cell surface) were assessed on cell pellets resuspended in sterile and $\mathrm{C}$-free seawater, after discarding the medium. Exo-enzymatic activities (i.e. activities of enzymes released into the medium) were measured on the $0.2 \mu \mathrm{m}$-filtered supernatant withdrawn after centrifugation. In both cases, sub-aliquots were incubated in the dark, at room temperature $(20 \pm$ $1^{\circ} \mathrm{C}$ ) for $1 \mathrm{~h}$ (fluorescence units increased linearly with time up to $3 \mathrm{~h}$ ). Enzymatic activities of isolated strains were normalized to cell number and, when appropriate, to biomass units. Total enzymatic activities in sediments from which 2 of the 11 strains were isolated (i.e. Ancona Port and Palombina Beach) were measured fluorometrically as described above and normalised to sediment dry weight.

Thraustochytrid counting and biomass. Cells were stained with Acriflavin and counted under epifluorescence microscope $\left(1000 x_{i}\right.$ Raghukumar \& Shaumann 1993). Maximal diameter of all thraustochytrid cells were measured with a micrometric eye-piece and individual biovolume was estimated by approximating cell shape to a sphere (Bongiorni et al. 2005). Thraustochytrid total biovolume was then converted into bio-

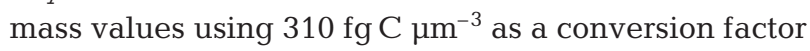
(Kimura et al. 1999).
Statistical analyses. Similarities among strains were assessed by cluster analysis using Bray-Curtis similarity matrixes, based on the presence/absence profiles of the investigated enzymes (using the Primer software, Primer-E). Differences in enzymatic activities among different strains were assessed using 1-way ANOVA. When significant differences were observed, a posthoc HSD-Tukey's test was performed to test for significant differences between means of groups.

\section{RESULTS AND DISCUSSION}

Enzymatic activity is a key step in the degradation of high-molecular weight organic matter (Meyer-Reil 1991, Hoppe 1993). In the marine environment, it is assumed that most of these activities are almost exclusively carried out by bacteria, but it is known that protists can produce extracellular enzymes (e.g. auto- and heterotrophic flagellates; Karner et al. 1994, Berges \& Falkowski 1996, Vrba et al. 1996, Sherr \& Sherr 1999, Stoecker \& Gustafson 2003, Mohapatra \& Fukami 2004).

In the present study, the ability of thraustochytrids to produce a wide variety of enzymes has been examined for the first time (Table 2). The analysis of the enzymatic pools of the 11 thraustochytrid strains indicates the presence of a wide spectrum of ecto- and exoenzymatic activities involved in the breakdown of proteins, carbohydrates and lipids, including refractory compounds, as indicated by the presence of a chitindegrading enzyme: the $\mathrm{N}$-acetyl- $\beta$-glucosaminidase.

Table 2. Enzymatic pools of the 11 thraustochytrid strains, according to the API ZYM system: (-) no activity; (+) medium activity; (++) high activity

\begin{tabular}{|c|c|c|c|c|c|c|c|c|c|c|c|}
\hline \multirow[t]{2}{*}{ Enzyme } & \multicolumn{4}{|c|}{ Sediments } & \multicolumn{5}{|c|}{ Mangroves-Seagrass-Algae } & \multicolumn{2}{|c|}{ Crustaceans } \\
\hline & GORO2 & PAL & POR & SAR3 & MAN2 & MAN6B & FAN5 & ULV B & ULV R & CR2 & GR2-1 \\
\hline Esterase (C4) & + & ++ & ++ & ++ & ++ & ++ & + & ++ & + & ++ & ++ \\
\hline Esterase lipase (C8) & + & ++ & ++ & ++ & ++ & + & + & ++ & - & ++ & ++ \\
\hline Lipase (C4) & + & ++ & ++ & + & + & + & - & + & - & ++ & ++ \\
\hline Leucine arylamidase & + & + & ++ & ++ & ++ & ++ & + & ++ & ++ & ++ & ++ \\
\hline Valine arylamidase & + & + & ++ & ++ & ++ & + & + & ++ & - & ++ & ++ \\
\hline Cystine arylamidase & - & + & + & + & + & + & + & + & - & + & + \\
\hline Trypsin & - & + & - & + & + & + & + & - & - & - & - \\
\hline$\alpha$ chymotrypsin & - & + & - & - & + & - & - & - & - & - & - \\
\hline Alkaline phosphatase & ++ & ++ & ++ & ++ & ++ & ++ & ++ & ++ & ++ & ++ & ++ \\
\hline Acid phosphatase & ++ & ++ & ++ & ++ & ++ & + & ++ & ++ & ++ & ++ & ++ \\
\hline Naphthol-AS-BI-phosphohydrolase & ++ & + & + & ++ & ++ & ++ & ++ & + & ++ & + & + \\
\hline$\alpha$-galactosidase & - & + & - & ++ & + & - & - & - & - & - & + \\
\hline$\beta$-galactosidase & + & ++ & + & + & + & + & + & + & + & ++ & + \\
\hline$\beta$-glucoronidase & - & - & - & - & - & - & + & - & + & - & + \\
\hline$\alpha$-glucosidase & - & - & - & + & + & - & + & - & - & - & - \\
\hline$\beta$-glucosidase & + & + & + & + & + & + & + & + & + & + & + \\
\hline$N$-acetyl- $\beta$-glucosaminidase & + & ++ & + & ++ & - & - & ++ & + & - & ++ & ++ \\
\hline$\alpha$-mannosidase & - & - & - & - & - & + & - & - & - & + & + \\
\hline$\alpha$-fucosidase & - & - & - & - & - & - & - & - & - & - & - \\
\hline
\end{tabular}


Chitin occurs commonly as an exo- and endoskeletal material in many marine organisms, representing a dominant fraction of particulate carbon and nitrogen in the marine environment (Gooday 1990, Place 1996). This enzyme was detected in 8 of the 11 strains, indicating that thraustochytrids can play an important role in the process of degradation of this biopolymer. The present study is also the first to reveal the thraustochytrids' ability to degrade lipids and organic P. In fact, all screened strains exhibited lipase, alkaline phophatase and acid phosphatase activities. The isolated strains displayed a certain selection in production of peptidases. Among peptide-degrading enzymes, leucine- and valyne-arylamidase were present in almost all strains, whereas $\alpha$-chymotrypsin and trypsin were observed in only 2 and 5 of the 11 strains, respectively. Carbohydrate degrading enzymes were poorly represented and, among these, only $\beta$-D-galactosidase and $\beta$-D-glucosidase were present in all the screened strains, while $\alpha$-fucosidase was not detected at all.

The cluster analysis revealed that the enzymatic pools of thraustochytrids were rather homogeneous, with a similarity close to $85 \%$ for most strains (Fig. 1). Therefore, all tested thraustochytrid species had the potential to degrade a wide variety of organic substrates, confirming that thraustochytrids play a role in the decomposition of organic detritus. In this regard, it is worth noting that the production of enzymes has occasionally been reported for thraustochytrids (Bahnweg 1979a,b, Raghukumar et al. 1994, Sharma et al. 1994, Bremer \& Talbot 1995, Raghukumar \& Raghukumar 1999) and their role in the decomposition of organic matter has been postulated in both benthic and pelagic environments (Kimura et al. 2001, Bongiorni \& Dini 2002, Bongiorni et al. 2005).

Ecto- and exo-enzymatic activities of $\beta$-D-glucosidase, L-aminopetidase, $\beta$-D-galactosidase, lipase and

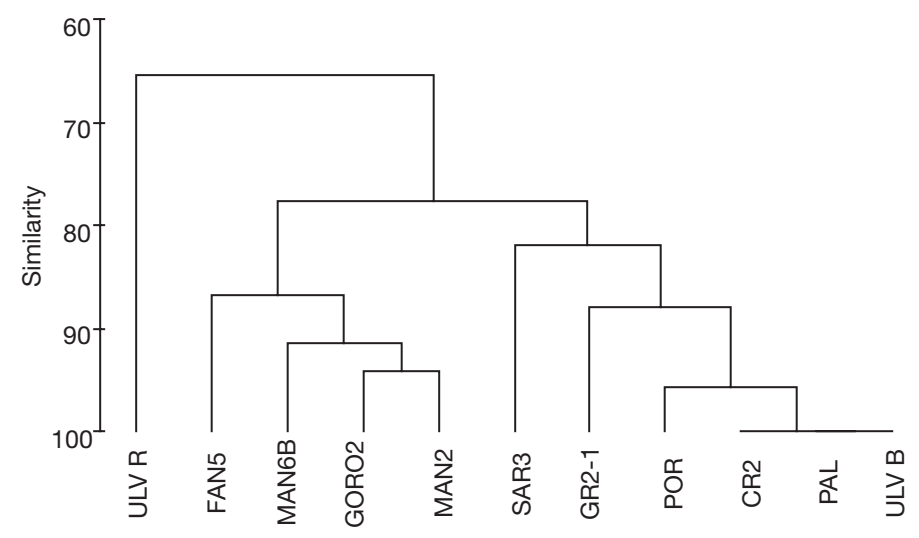

Fig. 1. Cluster analysis of similarities among the 11 thraustochytrid strains based on presence/absence matrix of the 19 tested enzymes alkaline phosphatase, expressed under fixed culturing conditions, are reported in Table 3. Density of cultured thraustochytrids ranged between 1.6 and $36.6 \times 10^{5}$ cells $\mathrm{ml}^{-1}$. Thraustochytrid strains exhibited very high ecto-enzymatic activities per cell, particularly for the enzymes alkaline phosphatase and aminopeptidase, which displayed the highest activities in all strains. This result suggests that thraustochytrids are implicated in $\mathrm{N}$ and $\mathrm{P}$ cycling.

Different strains displayed different activities for the investigated enzymes. For example, ecto- $\beta$-D-glucosidase and lipase activities per cell were highest in strains isolated from the algae Ulva rigida, and from tropical seagrass leaves (HSD-Tukey, $\mathrm{p}<0.05$ ). These strains also exhibited the highest values of ecto- $\beta$-Dgalactosidase (HSD-Tukey, $\mathrm{p}<0.05$ ). The relationship between enzymatic activity and substrate availability may be very close (Misic \& Fabiano 2005), so our results would support the hypothesis that thraustochytrid enzymatic pools are related to natural organic substrates. However, in the present study, all thraustochytrids were grown on the same medium, so the enzymes expressed by the tested strains should be regarded as constitutive rather than inducible. Therefore, our hypothesis needs further study and should only be considered with caution.

Exo-enzymatic activities of aminopeptidase accounted, on average, for more than $30 \%$ (range: 4 to $69 \%$ ) of the total enzymatic activity (measured as ectoplus exo-enzymatic activities) of tested thraustochytrids, whereas the exo-enzymatic activity of $\beta$-Dglucosidase and alkaline phosphatase represented on average $49 \%$ (range: 0 to $88 \%$ ) and $52 \%$ (range: 23 to $67 \%$ ) of their total pools, respectively. Exo- enzymatic activities of $\beta$-D-galactosidase and lipase represented, on average, $61 \%$ (range: 0 to $89 \%$ ) and $64 \%$ (range: 0 to $93 \%$ ), respectively, of the total activities.

These results led us to hypothesise that the exoenzymatic activities produced by thraustochytrids may contribute to the total extracellular enzymatic activities of marine sediment, with possible effects on organic matter cycling in benthic environments, and to the release of low molecular weight compounds available for thraustochytrids and other benthic heterotrophic microorganisms (Vetter \& Deming 1999).

As expected from differences in cell size, the results presented here indicate that the ecto-enzymatic activity per thraustochytrid cell was as much as 2 to 3 orders of magnitude higher than the activity per cell of marine bacteria reported by Martinez \& Azam (1993) and Martinez et al. (1996). However, assuming a mean bacterial biomass of $5 \times 10^{-8} \mu \mathrm{g} \mathrm{C}$ cell $^{-1}$, and the thraustochytrid biomass (range 2.0 to $6.9 \times 10^{-5} \mu \mathrm{g} \mathrm{C}$ cell $^{-1}$ ) estimated from cell size measurements, the enzymatic activities per unit of biomass of bacteria were up to 18 


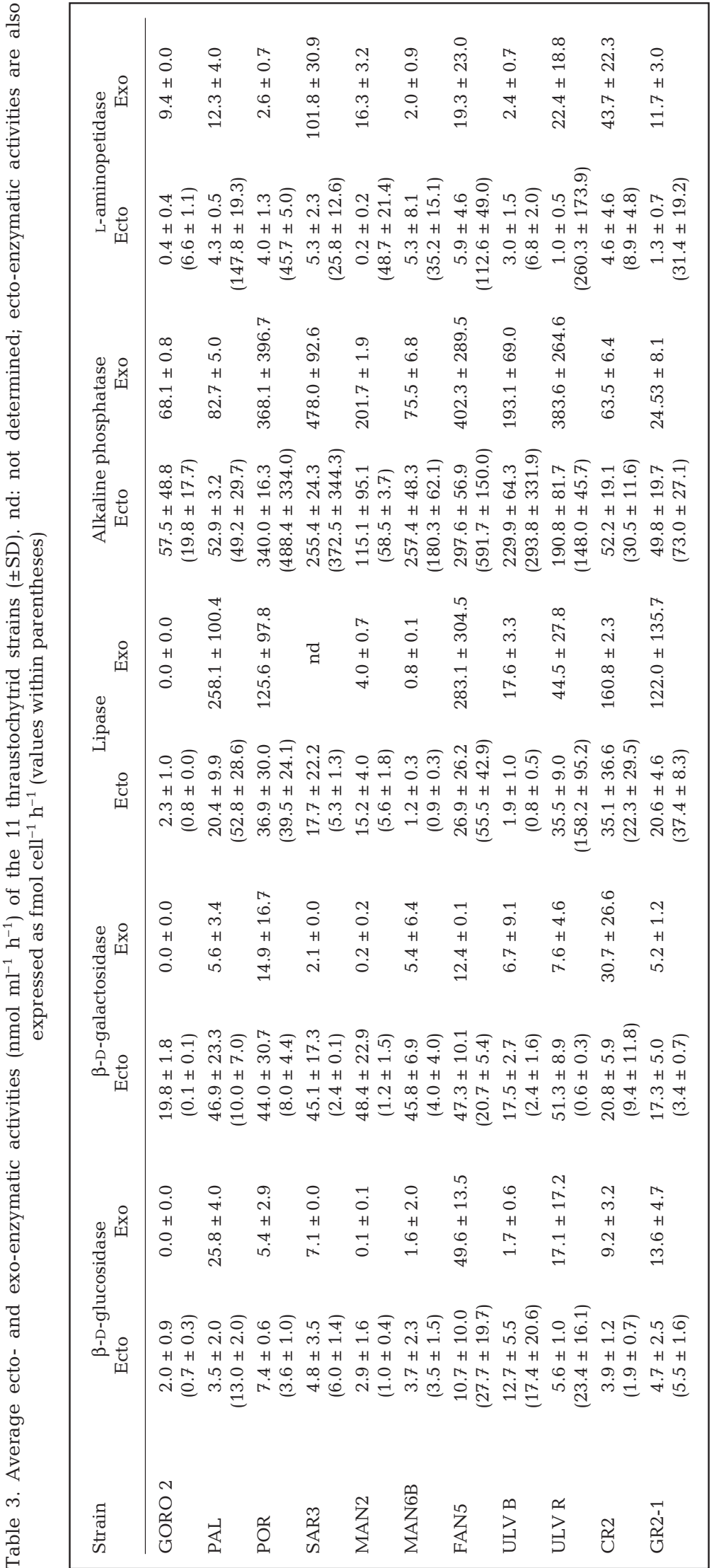

times higher then those of thraustochytrids.

Additional results were obtained from sediments collected in the Adriatic Sea, on which we carried out the thraustochytrid counting and the fluorimetric measurements of total enzymatic activities. In these sediments thraustochytrid abundance and biomass ranging from 6.7 to $7.4 \times 10^{3}$ cells $\mathrm{g}^{-1}$ and from 29.4 to $32.5 \mathrm{ng} \mathrm{C} \mathrm{g}^{-1}$, respectively, were similar to those reported elsewhere in coastal marine sediments (Bongiorni et al. 2005). Based on the activities per cell measured on the strains isolated from these sediments, we estimated the thraustochytrid contribution to the total enzymatic activity for $\beta$-D-glucosidase, aminopeptidase and alkaline phosphatase. Our results revealed that thraustochytrids may contribute up to 4,1 and $1.4 \%$ of the total $\beta$-D-glucosidase, aminopeptidase and alkaline phosphatase activities in the sediment, respectively (Table 4). Although these values are low, it is likely that the isolated culturable strain represents a minor fraction of the entire thraustochytrid community. This leads us to the hypothesis that thraustochytids might actually contribute to organic matter degradation processes in marine sediments.

Thraustochytrids have been repeatedly isolated from senescent seaweed, seagrass and mangrove leaves (Sharma et al. 1994, Bremer \& Talbot 1995, Raghukumar et al. 1995). Bongiorni et al. (2005) found higher abundance and biomass of thraustochytrids in sediments characterised by the presence of the Mediterranean seagrass Posidonia oceanica than in surrounding unvegetated sediments, and very high biomass values in sediments impacted by fish-farm biodeposition. In marine sediments characterised by the presence of seagrasses, structural carbohydrates represent the dominant biochemical component (Lawrence et al. 1989, Pusceddu et al. 2003). Accordingly, our investigation revealed that the highest levels of $\beta$-D-glucosidase and $\beta$-Dgalactosidase activities were measured in strains isolated from macroalgae and tropical seagrasses, further confirming the potential of thraustochytrids to degrade refractory organic compounds 
Table 4. Contribution ( $\mathrm{nmol} \mathrm{g}^{-1} \mathrm{~h}^{-1}$ ) of total $\beta$-D-glucosidase, L-aminopeptidase and alkaline phosphatase activities of thraustochytrids to total enzymatic activities in the sediments of Palombina Beach and in the sediments of the Ancona Port. nd: not determined

\begin{tabular}{|c|c|c|c|c|c|c|}
\hline & \multicolumn{2}{|c|}{$\beta$-D-glucosidase } & \multicolumn{2}{|c|}{ L-aminopetidase } & \multicolumn{2}{|c|}{ Alkaline phosphatase } \\
\hline & $\begin{array}{l}\text { Palombina } \\
\text { Beach }\end{array}$ & $\begin{array}{l}\text { Ancona } \\
\text { Port }\end{array}$ & $\begin{array}{l}\text { Palombina } \\
\text { Beach }\end{array}$ & $\begin{array}{c}\text { Ancona } \\
\text { Port }\end{array}$ & $\begin{array}{c}\text { Palombina } \\
\text { Beach }\end{array}$ & $\begin{array}{c}\text { Ancona } \\
\text { Port }\end{array}$ \\
\hline Thraustochytrids & 0.05 & 0.73 & 0.36 & 1.25 & nd & 7.54 \\
\hline Sediments & 18 & 31.4 & 400 & 35.1 & nd & 526.4 \\
\hline Contribution (\%) & 4 & 0.1 & 1.0 & 0.3 & nd & 1.4 \\
\hline
\end{tabular}

(Raghukumar \& Shaumann 1993, Raghukumar \& Raghukumar 1999).

The results of the present study open new perspectives on patterns of organic matter degradation processes in marine sediments. Further studies are required to better assess the quantitative role of thraustochytrids in this key step of the benthic microbial food chain.

Acknowledgements. We thank Prof. F. Boero for support by FIRB project Biodiversity no. RBAU012KXA 009.

\section{LITERATURE CITED}

Bahnweg G (1979a) Studies on the physiology of thraustochytriales I. Growth requirements and nitrogen nutrition of Thraustochytrium spp., Schizochytrium sp., Japonochytrium sp., Ulkenia spp. and Labyrinthuloides spp. Ver Inst Meeresforsch Bremerh 17:245-268

Bahnweg G (1979b) Studies on the physiology of thraustochytriales II. Carbon nutrition of Thraustochytrium spp., Schizochytrium sp., Japonochytrium sp., Ulkenia spp. and Labyrinthuloides spp. Ver Inst Meeresforsch Bremerh 17: 269-273

Benner R, Newell SY, Maccubbin AE, Hodson RE (1984) Relative contributions of bacteria and fungi to rates of degradation of lignocellulosic detritus in salt-marsh sediments. Appl Environ Microbiol 48:36-40

Berges JA, Falkowski PG (1996) Cell-associated proteolytic enzymes from marine phytoplankton. J Phycol 32:566-574

Bongiorni L, Dini F (2002) Distribution and abundance of thraustochytrids in different Mediterranean coastal habitats. Aquat Microb Ecol 30:49-56

Bongiorni L, Mirto S, Pusceddu A, Danovaro R (2005) Response of benthic protozoa and thraustochytrid protists to fish-farm impact in seagrass (Posidonia oceanica) and soft bottom sediments. Microb Ecol 50:268-276

Bremer GB, Talbot G (1995) Cellulolytic enzyme activity in the marine protist Schizochytrium aggregatum. Bot Mar 38:3741

Gooday GW (1990) The ecology of chitin degradation. Adv Microb Ecol 11:387-430

Hoppe HG (1993) Use of fluorogenic model substrates for extracellular enzyme activity (EEA) of bacteria. In: Kemp PF, Sherr BF, Sherr EB, Cole JJ (eds) Handbook of methods in aquatic microbial ecology. Lewis, Boca Raton, FL, p 423-431
Karner M, Ferrier-Pagès C, Rassoulzadegan F (1994) Phagotrophic nanoflagellates contribute to occurrence of $\alpha$-glucosidase and aminopetidase in marine environments. Mar Ecol Prog Ser 114:237-244

Kimura H, Fukuba T, Naganuma T (1999) Biomass of thraustochytrid protoctists in coastal water. Mar Ecol Prog Ser 189:27-33

Kimura H, Sato M, Sugiyama C, Naganuma T (2001) Coupling of thraustochytrids and POM, and of bacterio- and phytoplankton in a semi-enclosed coastal area: implication for different substrate preference by the planktonic decomposers. Aquat Microb Ecol 25:293-300

Lawrence JM, Boudouresque ChF, Maggiore F (1989) Proximate constituents, biomass and energy in Posidonia oceanica (Potamogetonaceae). PSZN I: Mar Ecol 10: $263-270$

Martinez J, Azam F (1993) Aminopeptidase activity in marine chroococcoid cyanobacteria. Appl Environ Microbiol 59: 3701-3707

Martinez J, Smith DC, Steward GF, Azam F (1996) Variability in ectohydrolytic enzyme activities of pelagic marine bacteria and its significance for substrate processing in the sea. Aquat Microb Ecol 10:223-230

Meyer-Reil LA (1991) Ecological aspects of enzymatic activity in marine sediments. In: Chrost RJ (ed) Microbial enzymes in aquatic environments. Springer-Verlag, Berlin, p 84-95

Misic C, Fabiano M (2005) Enzymatic activity on sandy beaches of the Ligurian Sea (NW Mediterranean). Microb Ecol 49:513-522

Mohapatra BR, Fukami K (2004) Production of aminopeptidase by marine heterotrophic nanoflagellates. Aquat Microb Ecol 34:129-137

Place AR (1996) The biochemical basis and ecological significance of chitin digestion. In: Muzzarelli RAA (ed) Chitin enzymology, Vol 2. Atec Edizioni, Grottammare, p 39-54

Porter KG, Feig YS (1980) The use of DAPI for identifying and counting aquatic microflora. Limnol Oceanogr 25:943-948

Pusceddu A, Dell'Anno A, Danovaro R, Manini E, Sarà G, Fabiano M (2003) Enzymatically hydrolyzable protein and carbohydrate sedimentary pools as indicators of the trophic state of detritus sink systems: a case study in the Mediterranean coastal lagoon. Estuaries 26:641-650

Raghukumar S (2002) Ecology of the marine protists, the Labyrinthulomycetes (Thraustochytrids and Labyrinthulids). Eur J Protistol 38:127-145

Raghukumar S, Raghukumar C (1999) Thraustochytrid fungoid protists in faecal pellets of the tunicate Pangea confoederata, their tolerance to deep-sea conditions and implication in degradation processes. Mar Ecol Prog Ser 190:133-140 
Raghukumar S, Schaumann K (1993) An epifluorescence microscopy method for direct detection and enumeration of the fungi-like marine protists, the thraustochytrids. Limnol Oceanogr 38:182-187

Raghukumar S, Sharma S, Raghukumar C, Sathe-Pathak V (1994) Thraustochytrid and fungal component of marine detritus. IV. Laboratory studies on decomposition of the leaves of the mangrove Rhizophora apiculata Blume. J Exp Mar Biol Ecol 183:113-131

Raghukumar S, Shathe-Pathak V, Sharma S, Raghukumar C (1995) Thraustochytrid and fungal component of marine detritus. III. Field studies on decomposition of leaves of the mangrove Rhizophora apiculata. Aquat Microb Ecol 9: $117-125$

Santangelo G, Bongiorni L, Pignataro L (2000) Abundance of thraustochytrids and ciliated protozoan in a Mediterranean sandy shore determined by an improved, direct method. Aquat Microb Ecol 23:55-61

Sharma S, Raghukumar C, Raghukumar S, Sathe-Pathak V, Chandramohan D (1994) Thraustochytrid and fungal components of marine detritus. IV. Laboratory studies on

Editorial responsibility: David A. Caron,

Los Angeles, California, USA decomposition of the brown alga Sargassium cinereum J. Ag. J Exp Mar Biol Ecol 175:217-242

Sherr EB, Sherr BF (1999) $\beta$-glucosaminidase activity in marine microbes. FEMS Microbiol Ecol 28:111-119

Stoecker DK, Gustafson DE (2003) Cell-surface proteolytic activity of photosynthetic dinoflagellates. Aquat Microb Ecol 30:175-183

Tiquia SM (2002) Evolution of extracellular enzyme activities during manure composting. J Appl Microbiol 92:764-775

Vetter YA, Deming JW (1999) Growth rates of marine bacterial isolates on particulate organic substrates solubilized by freely released extracellular enzymes. Microb Ecol 37: 86-94

Vrba J, Šimek K, Pernthaler J, Psenner R (1996) Evaluation of extracellular, high-affinity beta- $\mathrm{N}$-acetylglucosaminidase measurements from freshwater lakes: an enzyme assay to estimate protistan grazing on bacteria and picocyanobacteria. Microb Ecol 32:81-99

Wong MKM, Goh TK, Hodgkiss IJ, Hyde KD and 5 others (1998) Role of fungi in freshwater ecosystems. Biodivers Conserv 7:1187-1206

Submitted: April 26, 2005; Accepted: September 14, 2005 Proofs received from author(s): December 15, 2005 